\title{
Экспертиза
}

БРОДОВСКАЯ Елена Викторовна - доктор политических наук, доцент; профессор департамента политологии факультета социальных наук и массовых коммуникаций Финансового университета

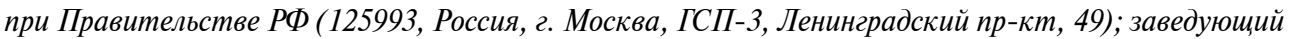
кафедрой социально-политических исследований и технологий Института истории и политики; главный научный сотрудник Института перспективных исследований Московского педагогического государственного университета (119991, Россия, г. Москва, ул. М. Пироговскал, 1/1; brodovskaуа@ inbox.ru)

ДОМБРОВСКАЯ Анна Юрьевна - доктор социологических наук, доцент; профессор департамента политологии факультета социальных наук и массовых коммуникаций Финансового университета при Правительстве РФ (125993, Россия, г. Москва, ГСП-3, Ленинградский пр-кт, 49); доцент кафедры социально-политических исследований и технологий Института истории и политики Московского педагогического государственного университета (119991, Россия, г. Москва, ул. М.Пироговская, 1/1; an-doc@yandex.ru)

\section{СОЦИАЛЬНАЯ БАЗА ИНФОРМАЦИОННОГО ПОТОКА ВНЕШНЕГО ДАВЛЕНИЯ В НОВЫХ МЕДИА КРЫМА И СЕВАСТОПОЛЯ}

\begin{abstract}
Аннотация. Статья представляет результаты прикладного исследования, решающего задачу анализа содержательных и социально-демографических характеристик цифровых профилей пользователей, вовлеченных в информационные потоки внешнего происхождения, таргетированные на крымскую и севастопольскую аудитории социальных медиа. Исследуются ценностные профили аккаунтов, владельцы которых связаны с информационной агрессией, осуществляемой с целью деконсолидации российского общества, снижения легитимности органов государственной власти. Когнитивное картирование содержания отобранных аккаунтов цифровых сообществ позволило осуществить структурный анализ контекстуальных, дискурсивных характеристик профилей - кейсов исследования, выявить соотношение гендерных, возрастных групп авторов данных аккаунтов, степень открытости контента и его виральный потенциал. По итогам исследования авторы делают заключение о преобладании среди ценностных профилей изученной части социально-медийной аудитории критиков действующей российской власти, имеющих широкий охват социально-медийного воздействия, и обосновывают проблему необходимости формирования культуры конвенционального политического участия как способа преодоления негативных эффектов деконсолидирующей мобилизации, в которую вовлечены пользователи с большими возможностями информационного воздействия.
\end{abstract}

Ключевые слова: социальные медиа, информационный поток, внешнее давление, информационное доминирование, информационная агрессия, ценностный профиль, социальная база информационного влияния, регионы-мишени, Крым, Севастополь, когнитивное картирование

И нформационное противоборство, борьба идентичностей и дискурсов в социально-медийном пространстве стали неотъемлемой частью цифровизации политической сферы общества. Несмотря на то что обозначенные процессы не являются зеркальными в онлайн- и офлайн-пространстве, в сегментах блогохостинга регионов с повышенным уровнем риска политической дестабилизации можно говорить о коэволюции дискурсов и социальной действительности. Так, особенности социальной структуры региона, наличие в ней миноритарных этнических и других групп с затрудненной ресоциализацией / не сложившейся национально-государственной идентичностью способствуют репликации дискурсов внешнего информационного давления, тогда как информационные потоки внешнего давления посредством цифровых коммуникаций оказывают влияние на общественное сознание и характер/направ- 
ленность взаимодействия таргетных групп. Подобная коэволюция дискурсов информационного потока внешнего давления и репертуара, комментарийной активности его таргетных групп в социальных медиа Крыма и Севастополя фиксируется в течение всего периода наблюдений - с 2015 г. по настоящее время. В частности, внешнее информационное давление, понимаемое как систематические информационные касания преимущественно манипулятивного характера, исходящие от центров и лидеров общественного мнения иностранного государства/государств, оказывающие воздействие на население регионамишени посредством цифровых коммуникаций, исходит в отношении Крыма и Севастополя от Украины и соответствующих цифровых инфраструктур. При этом группами-мишенями, т.е. основными адресатами данного информационного потока, выступают молодые люди, социализация которых прошла преимущественно в условиях украинской государственности, а также представители миноритарных этнических групп. Таким образом, сложносоставной характер регионального сообщества рассматривается менеджментом внешнего информационного давления в качестве своего рода точки уязвимости и повышенного уровня конфликтогенности.

Важным аспектом исследования внешнего информационного давления в крымском и севастопольском сегментах социальных медиа является определение его социальной базы. И если социальные группы-мишени в Крыму и Севастополе были ранее определены нами на основании опыта реализации прикладных политических исследований, то социальные, ценностные, психологические профили пользователей социальных медиа, вовлеченных в информационный поток внешнего давления, еще предстоит проанализировать. Решению поставленной исследовательской задачи посвящена данная статья.

Теоретическую основу исследования составляют концепции и идеи, сложившиеся в рамках дискурсивной психологии, относящейся к такому направлению, как социальный конструктивизм. Данный вид дискурс-анализа ориентирован на объяснение психических явлений в процессе социального взаимодействия посредством языка. Дискурс трактуется не как зеркало, отображение реальности, а как конструкция, создаваемая из лингвистического материала. Дискурсивная психология изучает, как люди обычно, в рамках повседневной деятельности сообщают и объясняют действия и события, как они характеризуют участников этих событий и как они управляют различными последствиями. Объектом изучения в дискурсивной психологии выступает не столько сама личность, сколько выраженные в речи и текстах ее установки и убеждения. Согласно Р. Харре, исследование обыденного языка личности в социальном и культурном контекстах выступает источником познания человека [Psychology for... 2012]. Д. Поттер и М. Ветерелл определили основные положения дискурсивной психологии, выразив их в следующих трех принципах: созданный из слов дискурс конструирует социальный мир; дискурс направлен на социальные действия; дискурсивные действия обусловлены институциональным, коммуникативным и риторическим контекстами. Таким образом, психологические дискурсы конструируются, ориентируются и понимаются в процессе социального взаимодействия, а личность формирует свою идентичность в социальной среде, познавая мир как наборы языковых символов [Potter, Wetherell 1987]. Исходя из задач исследования, особый интерес в дискурсивной психологии представляет выделение репертуаров интерпретации, т.е. наборов понятий, посредством которых происходит описание и оценка социальных явлений, событий и действий. Они обычно выражены в стереотипах, метафорах, клише, фигурах речи и т.д. Текстовой анализ дискурсив- 
ной психологии рассматривает, как авторы используют лексику для того, чтобы представить, позиционировать себя и других в определенной ситуации [Кутковая 2014: 6].

Методологическая база исследования включает в себя следующие компоненты:

- социальный конструктивизм (дискурсивная психология) [Potter, Wetherell 1987];

- сетевой подход (концепция сетевой культуры) [Mercer 2011];

- новый институционализм (теория неполной рациональности) [Simon 1978];

- когнитивный подход (когнитивная карта как эмпирический инструмент политического исследования) [Толмен 1980];

- психологическое направление в пост-бихевиорализме [Инглхарт 2018].

Дизайн исследования. На первом этапе был осуществлен поиск социальномедийных сообществ ${ }^{1}$ в наиболее популярном блогохостинге России ВКонтакте, отвечающих требованиям соответствия их контента критерию вовлеченности в производство потоков, обслуживающих внешнее информационное давление на Крым и Севастополь, параметрам интенсивности, актуальности публикационной активности и влиятельности (широта охвата пользовательской аудитории не менее 1000 участников, исключение составили 2 группы, имеющие большое значение для содержательного анализа, обладающие аудиторией не более 400 пользователей). На втором этапе были отобраны посты данных групп за период с 01.01.2020 по 01.07.2020, получившие наибольший пользовательский резонанс в виде комментариев, лайков и перепостов. Пользователи, проявившие активность в отношении отобранных постов, составили пул профилей - кейсов исследования (282 профиля). На третьем этапе было осуществлено когнитивное картирование [Бродовская, Домбровская, Карзубов 2018] содержания этих аккаунтов. Анализировалось по 50 материалов (документов), размещенных авторами профилей в анализируемый период, отобранных методом систематической выборки. Общее число проанализированных сообщений составило 14100.

На четвертом этапе был осуществлен анализ базы когнитивного картирования с применением программы SPSS Statistics 24.0. Задачами данного этапа были сегментирование профилей по содержательным и социально-демографическим характеристикам, выявление сопряженности между данными переменными.

Pезультаты. Когнитивное картирование содержания аккаунтов авторов, вовлеченных в потоки внешнего информационного давления на Крым, осуществлено в соответствии со следующими параметрами измерения: содержательная направленность аккаунта; позиция в отношении присоединения Крыма и Севастополя к России; статус аккаунта; гендерная принадлежность автора аккаунта; возраст автора аккаунта; число друзей и подписчиков (масштаб влиятельности автора аккаунта).

Наиболее значимый параметр изучения профилей - их содержательное наполнение. В соответствии с детальным анализом их контента были выделены 6 типов профилей, материалы которых служат отражением различных цен-

1 Сообщества - кейсы анализа: м Крим - це Україна | Геть руки від Криму œ (https:// vk.com/uakrim); Лента новостей Крыма (https://vk.com/public60779074), Крымские татары - Къырымтатарлар (https://vk.com/qirimli_balalar); Free Speech (https://vk.com/public88390122); Информационная война (https://vk.com/club4121067); Новости Крым - UA (https://vk.com/club76624197); Че тама? (https://vk.com/public150765683); Геополитика. Политика. Аналитика. Вооружение (https://vk.com/public102868701); Ложь и абсурдность СМИ на фоне массового запоя (https://vk.com/club6569643); Крымский бандеровец /// Crimean banderovec (https://vk.com/public94269450). 
ностных ориентаций их авторов. Данные профили сегментированы в 2 группы: имеющие преимущественно политический контент и характеризующиеся главным образом неполитическим содержанием. Профили первой группы можно условно разделить по двум осям значений: 1) «лоялисты»- сторонники конструктивных отношений с властью; 2) «критики» - противники конструктивных отношений с властью. Среди профилей преимущественно неполитического характера: 1) «сторонники асоциальных ценностей»; 2) «прагматики»; 3) «микросоциалы»; 4) «созерцатели».

Подчеркнем, что суммарно все политикоориентированные профили, вошедшие в выборочную совокупность исследования, составили 60,9\% всех обследованных аккаунтов. Среди профилей с преимущественно политическим контентом явно доминируют аккаунты «критиков» $(46,4 \%)$. Это говорит о том, что вовлечение пользователей, которым принадлежат эти аккаунты, во внешние информационные потоки, нацеленные на Крым и Севастополь, абсолютно не случайно. Их интерес к контенту, подрывающему доверие к действующей российской власти, деконструктивная политическая позиция, неготовность к конвенциональным формам политической активности проявляются во многом в содержании их собственных аккаунтов.

Среди профилей преимущественно неполитического характера выделяются три относительные доминанты: аккаунты «прагматиков» $(13,0 \%)$, «созерцателей» $(12,3 \%)$ и «сторонников асоциальных ценностей» $(8,7 \%)$. Таким образом, в аудиторию внешних информационных потоков, таргетированных на Крым и Севастополь, помимо пользователей с явно антиправительственными установками, входит часть россиян, рассматривающих социальные медиа в качестве инструмента предпринимательской активности, а также пользователи, предпочитающие контент, не согласующийся с нормами морали и нравственности. Общей характеристикой владельцев всех этих профилей служит способность к социальному вызову и неготовность к конструктивному взаимодействию с органами власти.

Проанализируем дискурсивные практики аккаунтов представителей различных ценностных профилей.

Ценностные профили аккаунтов с преимущественно политическим контентом, авторы которых вовлечены в потоки внешнего информационного давления на Крым и Севастополь, следующие.

«Лоялисты»: «Хотим поблагодарить нашего Президента за то, ...что любит Россию... Я радуюсь, что мой Президент - Путин! (женщина, 73 года); «По поводу непризнания Украиной итогов голосования Крыма по поправкам в Конституцию - Крыму не требуется этого признания... наш Президент В.В. Путин!» (мужчина, 65 лет); «Крым - это Россия!.. В Крыму при напоминании о возврате на Украину все крестятся, ...не хотят возврата к нищете и бесправию при украинской власти» (женщина, 42 года); «Мы рады жить в новом российском Крыму!..» (мужчина, 34 года).

«Критики». Данный тип профиля предполагает размещение в аккаунте обвинительных заявлений, иронии, саркастических оценок действий представителей российской власти. Данная критика имеет широкий спектр адресатов:

- президент В.В. Путин:

«С 1999 по 2020 годы поднялись: пенсионный возраст, НДС, стоимость бензина, количество чиновников, олигархов, президентский срок, число бедных, закредитованность россиян, цены на продукты питания» (женщина, 30 лет);

- органы правопорядка:

«Стреляют собак. Избивают людей. ...Каких еще преступлений ждать народу от стражей порядка?» (мужчина, 53 года); 
- референдум по внесению поправок в Конституцию РФ:

«Проголосовали за дальнейшее стабильное обнуление России» (женщина, 25 лет).

Особым типом анализируемого ценностного профиля служит такой вид аккаунтов, авторы которых, являясь в большинстве своем украинцами, обвиняют Россию в агрессии и захватнической политике.

«Я не прощу тебя, Россия, никогда... В мой край кацапская орда... на танках смело заезжала» (женщина, 39 лет); «Ненавижу кацапов... Спустя 70 лет наследница Сталинского СССР - Путинская Россия - добралась до родины крымских татар снова» (женщина, 48 лет).

«Критики» зачастую имеют в качестве объекта своего недовольства также и власть Украины.

«Зеленский в короне - а корона - вирус!» (мужчина, 27 лет); «Зеленский зеленый осел» (мужчина, 32 года); «Конституция не работает, страна (Украина) под контролем улицы (нацистов, бандеровцев)» (мужчина, 21 год); «Проще Мишу зачистить, чем убрать коррупцию с украинских судов, таможни, налоговой» (мужчина, 49 лет); «Не надо им мешать, они сами (Правительство Украины) “ушатают” Украину» (мужчина, 67 лет).

Перечислим ценностные профили аккаунтов с преимущественно неполитическим контентом, авторы которых вовлечены в потоки внешнего информационного давления на Крым и Севастополь.

«Созерцатели» $(12,3 \%)$ размещают известные цитаты и афоризмы, относящиеся к сфере человеческих взаимоотношений, понятий любви, добра, дружбы, прочих нравственных категорий. Свое отношение к крымской повестке авторы анализируемых аккаунтов выражают с помощью выставления оценок «нравится» (лайков) в отношении постов, направленных на критику позиции российской власти по отношению к Украине, воссоединения РФ и Крыма. Вместе с тем в своих социально-медийных профилях пользователи указанного ценностного типа, как правило, не размещают сообщения антиправительственного характера.

«Прагматики» $(13,0 \%)$ преследуют цель самопрезентации и использования социально-медийной площадки для зарабатывания денег.

«Микросоциалы» $(2,9 \%)$ - пользователи, которые чаще всего размещают фотосрезы событий из жизни своей семьи, делают акцент в контенте профиля на семейные ценности и ценности дружбы.

«Сторонники асоциальных ценностей» $(8,7 \%)$ - пользователи, размещающие на своей странице материалы, не отвечающие принципам нравственности, часто оскорбительного характера для феминной гендерной группы, этнических меньшинств, других социальных общностей.

По результатам структурно-логического контент-анализа содержания перечисленных ценностных профилей отобранных аккаунтов около 4/5 (76,6\%) владельцев проанализированных профилей выражают критическое мнение по отношению к воссоединению РФ и Крымского полуострова, еще 13,9\% не имеют явно репрезентированной на страницах своего аккаунта установки по данному вопросу, и только 9,5\% авторов изученных профилей интенсивно представляют в своем аккаунте позицию одобрения присоединения Крыма и Севастополя к России. Совершенно четко прослеживается закономерность более активного вовлечения во внешние информационные потоки давления на Крым тех пользователей, которые не разделяют так называемый Крымский консенсус.

На рис. 1 показано, как сопряжены некоторые ценностные профили и позиции их авторов по отношению к воссоединению Крыма и Севастополя к России. 


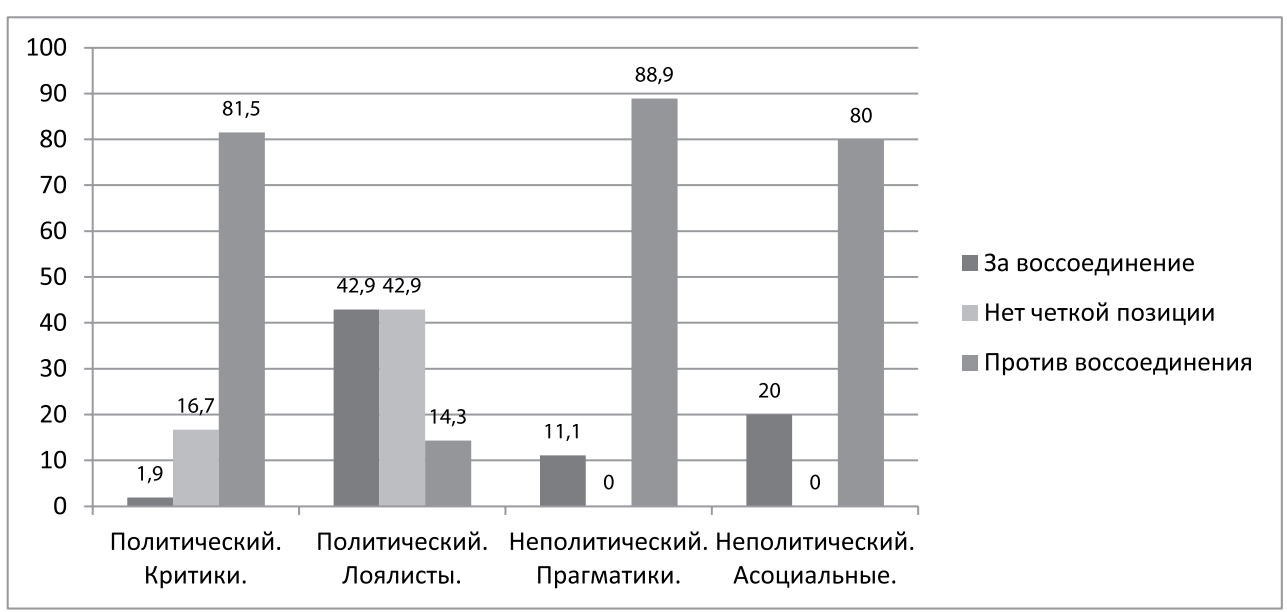

Рисунок 1. Сопряженность ценностных профилей авторов аккаунтов (выборочно), имеющих политический и неполитический фокус контента, и их позиция по отношению к воссоединению Крыма и Севастополя с Россией, \%

Наиболее активно свою непримиримую позицию в отношении воссоединения Крыма и РФ выражают «прагматики», «критики российской власти» и «трансляторы асоциального контента». Почти вдвое менее интенсивная негативная реакция поступает от тех авторов профилей, вовлеченных во внешний поток информационного давления на Крым и Севастополь, которые имеют критические установки в отношении власти Украины.

Согласно данным исследования, лишь половина аккаунтов, авторы которых вовлечены во внешние информационные потоки, таргетированные на Крым и Севастополь $(56,1 \%)$, показывают свое полное имя и фамилию в профиле социального медиа и имеют открытый профиль. Обращает на себя внимание тот факт, что почти каждый пятый пользователь $(17,8 \%)$, вовлеченный в анализируемые потоки, имеет закрытый профиль, что зачастую свидетельствует о нежелании афишировать контент своего аккаунта. Еще более явно говорит в пользу неконструктивности и незаконности размещаемых материалов факт «забанивания» (запрета функционирования администратором социального медиа) более чем пятой части профилей пользователей, составляющих аудиторию внешнего информационного воздействия $(21,3 \%)$. Таким образом, совершенно очевидным представляется неконструктивный характер существенной части профилей авторов, входящих в состав аудитории изучаемых социально-медийных потоков.

На рис. 2 показано сопряжение между гендерной принадлежностью автора и статуса профиля.

Согласно данным исследования, среди авторов открытых профилей с полным именем почти втрое меньше представительниц феминной гендерной группы; вместе с тем среди владельцев закрытых профилей существенно больше мужчин. Таким образом, маскулинная позиция аудитории, вовлеченной во внешние информационные потоки, выражается в полном закрытии контента своего профиля, феминная - в «закодировании» своей персоны с помощью ников, псевдонимов.

Общая тенденция к закрытости персональных данных у авторов аккаунтов - объектов эмпирического анализа проявляется также и в том, что лишь в $15,7 \%$ исследованных профилей представлены фото авторов, показывающие их повседневность и наиболее яркие события жизни. 


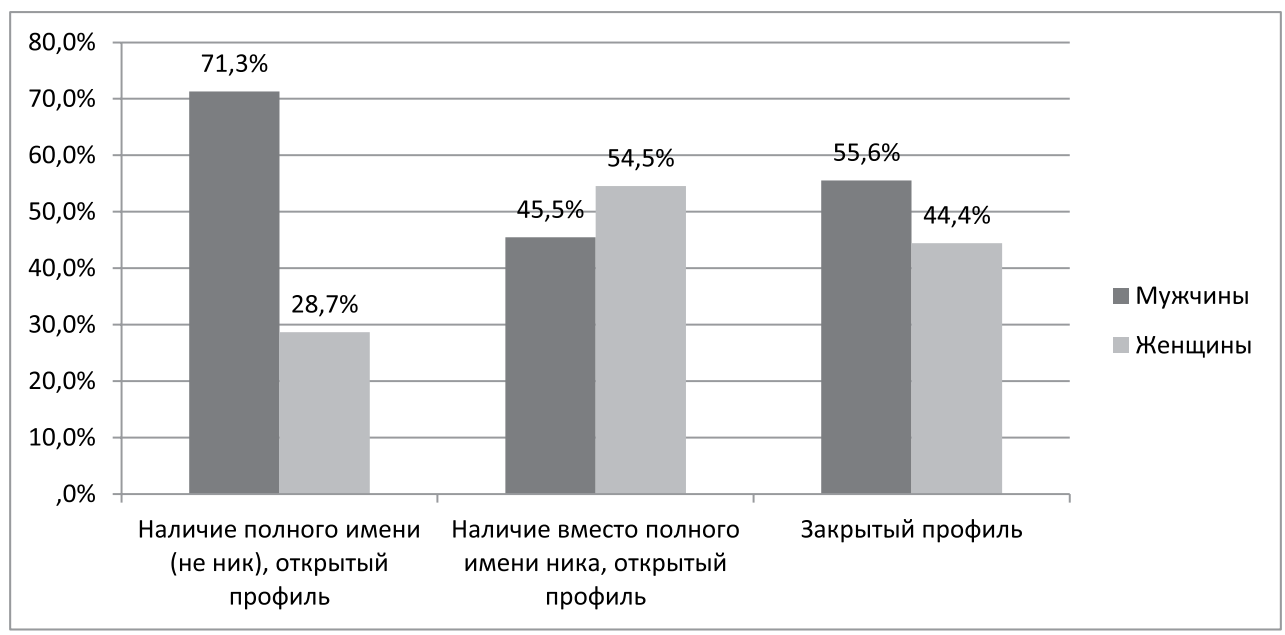

Рисунок 2. Статус аккаунта в зависимости от гендерной принадлежности автора, \%

Гендерная принадлежность около $1 / 3$ авторов аккаунтов $(31,3 \%)$ неизвестна по разным причинам (ник вместо имени, закрытый профиль, аккаунт с запрешенным контентом). Из тех профилей, пол владельцев которых удалось идентифицировать, 67,7\% - мужчины и 32,3\% - представители феминной гендерной группы. Таким образом, налицо меньшая включенность женщин во внешние информационные потоки влияния на Крым и Севастополь; фактически вдвое чаще склонна к вовлечению в данные потоки маскулинная гендерная группа.

Авторы более 2/3 аккаунтов $(67,5 \%)$ - представители молодого поколения (от 14 до 30 лет), что очевидным образом указывает на молодежь как общность, наиболее сензитивную к теме критики действующего режима по отношению к вопросу о принадлежности Крыма.

Важной характеристикой авторов профилей - объектов анализа служит тот факт, что среднее число подписчиков их аккаунтов - 2326 пользователей. Таким образом, в большинстве своем аудитория внешних потоков информационного влияния на Крым - это лидеры мнений онлайн-сетевого пространства, имеющие широкий охват пользовательской аудитории, включенной в сферу их информационного воздействия.

В заключение отметим, что исследование позволяет сделать вывод о следующих характеристиках пользовательской аудитории, вовлеченной в потоки внешнего информационного воздействия на Крым и Севастополь.

Среди ценностных профилей в данной части социально-медийной аудитории преобладают критики действующей российской власти, осуждающие ее за присоединение Крымского полуострова к РФ. Эта же критическая позиция также характерна и для некоторых иных ценностных типов: «прагматиков» и «трансляторов аморального контента». Несмотря на существенную долю закрытых профилей пользователей, входящих в аудиторию внешнего информационного давления на Крым, все авторы указанных ценностных профилей аккаунтов кейсов исследования имеют широкий охват социально-медийного воздействия. Явное доминирование среди онлайн-сетевых лидеров мнений, вовлеченных в указанные потоки, молодого поколения России свидетельствует о серьезной проблеме - необходимости формирования культуры конвенционального политического участия, что может способствовать преодолению негативных эффек- 
тов деконсолидирующей мобилизации, в которую вовлечены российские пользователи с большим потенциалом информационного воздействия.

Одним из перспективных направлений продолжения исследования социальной базы внешних потоков информационного давления является составление онтологий языка пользователей, дифференцированных по социальным, ценностным и психологическим профилям для последующей автоматизации сбора, обработки и интеллектуального анализа данных.

Интересными задачами на будущее также выступают такие, как:

- выявление стимульных визуальных и текстовых материалов, направленных на актуализацию протестного потенциала и неконвенциального поведения молодых онлайн-пользователей полуострова, оказавшихся в сфере влияния лидеров и центров общественного мнения украинских информационных потоков в крымском сегменте социальных медиа;

- поиск возможностей по трансформации поведенческих стратегий молодых крымчан с затрудненной/конфликтной ресоциализацией на основе моделирования игрового пространства;

- обнаружение визуальных и текстовых триггеров актуализации протестного потенциала и неконвенциального поведения молодых крымчан с затрудненной/конфликтной ресоциализацией на основе окулографического анализа (тип нейровизуальной психодиагностики) [Николаева и др. 2020: 62];

- расчет и анализ вегетативного коэффициента при восприятии молодыми крымчанами с затрудненной/конфликтной ресоциализацией визуальных и текстовых триггеров актуализации протестного потенциала и неконвенциального поведения;

- разработка программы рекомендаций, направленной на противодействие антироссийской риторике, и купирование негативных общественно-политических эффектов внешнего информационного давления.

Статья подготовлена в рамках поддержанного РФФИ проекта Севастопольского государственного университета «Украинские информационные потоки в крымском сегменте социальныхмедиа:риски и технологии преодоления негативных эффектов антироссийской риторики в онлайновой среде» (№ 18-011-00937 на 2018-2020 годы).

\section{Список литературы}

Бродовская Е.В., Домбровская А.Ю., Карзубов Д.Н. 2018. Коммуникационная структура украинских социально-медийных потоков о развитии Крыма в составе РФ: социально-медийная аналитика и дискурсивный анализ. - Вестник Московского государственного областного университета: электронный журнал. № 4. С. 3-32. Доступ: https://evestnik-mgou.ru/ru/Articles/View/923 (проверено 10.07.2020).

Инглхарт Р.2018. Культурная эволюция: как изменяются человеческие мотивации и как это меняет мир (пер. с англ. С.Л. Лопатиной, под ред. М.А. Завадской, В.В. Костенко, А.А. Широкановой; науч. ред. Э.Д. Понарин). М.: Мысль. 347 с.

Кутковая Е.С. 2014. Дискурс-анализ эмоций и теория позиционирования в исследовании социального события. - Психологические исследования. Т. 7. № 34.

Николаева Л.П., Огнев А.С., Лихачева Э.В., Галой Н.Ю., Розенова М.И., Фан Ц. 2020. Применение окулометрии для определения интерактивных установок личности. - Психология. Историко-критические обзоры и современные исследования. Т. 9. № 2А. С. 61-71.

Толмен Э. 1980. Когнитивные карты у крыс и человека. - Хрестоматия по 
истории психологии (под ред. П.Я. Гальперина, А.Н. Ждан). М.: Изд-во МГУ. C. 63-69.

Mercer C. 2011. Culturelinks: Cultural Networks and Cultural Policy in the Digital Age. Networks: The Evolving Aspects of Culture in the $21^{\text {st }}$ Century. Zagreb: Institute for International Relations Culturelink Network. P. 31-45.

Potter J., Wetherell M. 1987. Discourse and Social Psychology: Beyond Attitudes and Behaviour. London: SAGE Publications Ltd. 256 p.

Psychology for the Third Millennium (ed. by R. Harré, F.M. Moghaddam). 2012. London; Los Angeles: SAGE. Viii + $312 \mathrm{c}$.

Simon H.A. 1978. Rationality as Process and as Product of Thought. Richard T. Ely Lecture. - American Economic Review. May 1978. Vol. 68. No. 2. P. 1-16.

BRODOVSKAYA Elena Viktorovna, Dr.Sci. (Pol.Sci.), Associate Professor; Professor of the Department of Political Science, Faculty of Social Sciences and Mass Communications, Financial University under the Government of the Russian Federation (49 Leningradsky Ave, GSP-3, Moscow, Russia, 125993); Head of the Chair of Socio-Political Research and Technology, Institute of History and Politics, Moscow State Pedagogical University (1/1 Malaya Pirogovskaya St, Moscow, Russia, 119435; brodovskaya@inbox.ru)

DOMBROVSKAYA Anna Yur'evna, Dr.Sci. (Soc.), Associate Professor; Professor of the Department of Political Science, Faculty of Social Sciences and Mass Communications, Financial University under the Government of the Russian Federation (49 Leningradsky Ave, GSP-3, Moscow, Russia, 125993); Associate Professor of the Chair of Socio-Political Research and Technology, Institute of History and Politics, Moscow State Pedagogical University (1/1 Malaya Pirogovskaya St, Moscow, Russia, 119435; an-doc@yandex.ru)

\title{
HUMAN RESORCE FOR EXTERNAL INFORMATIONAL INFLUENCE TARGETED TO CRIMEAN AND SEVASTOPOL SOCIAL MEDIA
}

\begin{abstract}
The article presents the results of an applied research that solves the problem of studying the content and sociodemographic characteristics of the social media profiles of users involved in information flows of external origin, targeted to the Crimean and Sevastopol social media audiences. The authors examine the value profiles of accounts whose owners are associated with information aggression carried out with the aim of deconsolidating Russian society and reducing the legitimacy of public authorities. Cognitive mapping of the content of the selected digital community accounts allowed us to carry out a structural analysis of contextual, discursive characteristics of profiles - case studies, the ratio of gender and age groups of authors of these accounts, the degree of openness of content and its viral potential. On the results of the study, the authors conclude about the prevalence of critics of the current Russian government among the value profiles of the studied part of the socio-media audience with a wide coverage of the socio-media impact. The problem of the need for the formation of a culture of conventional political participation among young people, as well as a way to overcome the negative effects of deconsolidating mobilization, in which Russian users with great opportunities for informational impact, are substantiated.
\end{abstract} Keywords: social media, information flow, external pressure, information dominance, information aggression, value profile, human resource of information influence, target regions, Crimea, Sevastopol, cognitive mapping 